\title{
Effects of 8 weeks pre-workout dietary supplement ingestion with and without synephrine on blood chemistry panel
}

\author{
YP Jung ${ }^{1 *}$, R Dalton ${ }^{1}$, C Rasmussen ${ }^{1}$, P Murano $^{2}$, CP Earnest ${ }^{1,3}$, RB Kreider $^{1}$ \\ From The Twelfth International Society of Sports Nutrition (ISSN) Conference and Expo \\ Austin, TX, USA. 11-13 June 2015
}

\begin{abstract}
Background
A number of nutritional strategies have been developed to optimize nutrient delivery prior to exercise. As a result, a number of pre-workout supplements have been developed to increase energy availability, promote vasodilation, and/ or positively affect exercise capacity. The purpose of this study was to examine the effects of 8 weeks pre-workout dietary supplement ingestion with and without synephrine on blood chemistry panel.
\end{abstract}

\section{Methods}

In a double-blind, randomized and placebo-controlled manner; 80 apparently healthy and resistance-trained men $\left(21.76 \pm 3.59 \mathrm{yr}, 15.29 \pm 6.19 \%\right.$ fat, $\left.25.60 \pm 4.03 \mathrm{~kg} / \mathrm{m}^{2}\right)$ ingested in a randomized and counterbalanced manner a dextrose flavored placebo (P); a pre-workout supplement (PWS) containing $3.0 \mathrm{~g}$ beta alanine, $2 \mathrm{~g}$ creatine nitrate, $2 \mathrm{~g}$ arginine $\mathrm{AKG}, 300 \mathrm{mg} \mathrm{N}$-acetyl tyrosine, $270 \mathrm{mg}$ caffeine, 15mg Mucuna pruriens; or, the PWS with 20mg synephrine $(\mathrm{PWS}+\mathrm{S})$, and then had blood donation at week 0 , week 4 , and week 8 . The participants had resistance training 4 times per week during 8 weeks supplementation. Data were analyzed by repeated measure ANOVA and presented as mean $(95 \% \mathrm{CI})$ delta change from baseline.

\section{Results}

Repeated MANOVA revealed no significant differences among groups in blood urea nitrogen $(\mathrm{BUN})(\mathrm{p}=0.62)$ and creatinine $(\mathrm{CRE})(\mathrm{p}=0.27)$, and the ratio of $\mathrm{BUN} /$ CRE $(B C r)(p=0.20)$. An overall Wilks' Lambda analysis

\footnotetext{
* Correspondence: peterjung@hlkn.tamu.edu

${ }^{1}$ Exercise \& Sport Nutrition Lab, Texas A\&M University, College Station, TX, USA

Full list of author information is available at the end of the article
}

showed significant time effects $(\mathrm{p}<0.01)$ in mean changes in BUN (unit conversion to $\mathrm{mg} / \mathrm{dl}$ by $\mathrm{mmol} / \mathrm{l} \times$ $2.8011)(2.79 \mathrm{mg} / \mathrm{dl} ; 1.58,4.00)$ at week 8 , CRE (unit conversion to $\mathrm{mg} / \mathrm{dl}$ by $\mu \mathrm{mol} / \mathrm{l} \times 0.0113)(-0.35 \mathrm{mg} / \mathrm{dl}$; $-0.49,-0.21)$ at week 4 and $(-0.16 \mathrm{mg} / \mathrm{dl} ;-0.28,-0.05)$, and BCr: $(8.17 ; 4.01,12.33)$ at week 4 and $(7.02 ; 3.02$, $11.02)$ at week 8 . Greenhouse-Geisser univariate analysis revealed no time $\times$ group interaction of BUN $(p=0.54)$, CRE $(p=0.78)$, and $B C r(p=0.62)$. In liver enzymes, there were no significant differences among groups in alkaline phosphatase (ALP) $(\mathrm{p}=0.24)$, alanine amino transferase (ALT) $(\mathrm{p}=0.74)$, and aspartate amino transferase (AST) $(p=0.47)$. Delta analysis revealed significant difference in ALP: $(-11.23 \mathrm{U} / \mathrm{L} ;-13.93,-8.5)$ at week 4 and $(-5.44 \mathrm{U} / \mathrm{L} ;-8.48,-2.4)$ at week 8 . LSD Post hoc analysis revealed no significant mean changes in liver enzymes; however, there was a significant difference $(\mathrm{p}=$ 0.04) of ALP between PWS+S (-3.44 U/L; -6.52, -0.36) and PWS $(-7.86 \mathrm{U} / \mathrm{L} ;-10.88,-4.84)$ compared with $\mathrm{P}$ $(-5.36 \mathrm{U} / \mathrm{L} ;-8.388,-2.34)$. However, the range of both groups PWS + S: $(68.14 \pm 17.39 \mathrm{U} / \mathrm{L})$ at week 4 and $(74.44$ $\pm 19.64 \mathrm{U} / \mathrm{L})$ at week 8 and PWS: $(87.20 \pm 24.72 \mathrm{U} / \mathrm{L})$ at week 4 and $(78.49 \pm 24.96 \mathrm{U} / \mathrm{L})$ at week 8 were within safe clinical range (30-92 U/L). There were no significant time $(\mathrm{p}=0.23)$ and time $\times$ group interaction $(\mathrm{p}=0.78)$ of creatine kinase $(\mathrm{CK})$ and lactate dehydrogenase (LDH), no significant time $\times$ group interaction $(\mathrm{p}=0.78)$ of total cholesterol, LDL-C, HDL-C and triglyceride, and a significant time effect $(\mathrm{p}<0.01)$ but no time $\times$ group effect $(p=0.083)$ of glucose levels.

\section{Conclusion}

Ingesting a dietary PWS or PWS + S for 8 weeks had no adverse effect on kidney function, liver enzymes, blood lipid levels, muscle enzymes, and blood sugar levels. These 
findings are in agreement with other studies testing similar ingredients.

\section{Acknowledgements}

Supported by Nutrabolt International, Inc. (Bryan, TX).

\section{Authors' details}

${ }^{1}$ Exercise \& Sport Nutrition Lab, Texas A\&M University, College Station, TX USA. ${ }^{2}$ Institute for Obesity Research \& Program Evaluation, Texas A\&M University, College Station, TX, USA. ${ }^{3}$ Nutrabolt International Inc., Bryan, TX, USA

Published: 21 September 2015

doi:10.1186/1550-2783-12-S1-P4

Cite this article as: Jung et al:: Effects of 8 weeks pre-workout dietary supplement ingestion with and without synephrine on blood chemistry panel. Journal of the International Society of Sports Nutrition 2015

12(Suppl 1):P4.

Submit your next manuscript to BioMed Central and take full advantage of:

- Convenient online submission

- Thorough peer review

- No space constraints or color figure charges

- Immediate publication on acceptance

- Inclusion in PubMed, CAS, Scopus and Google Scholar

- Research which is freely available for redistribution 